\title{
Comparative studies of diet selection by Churro and Merino genotypes grazing on a hill shrub community
}

\author{
P. R. Revesado, A. R. Mantecón, P. Frutos and J. S. González \\ Estación Agrícola Experimental, CSIC 24080 León, Spain
}

\section{Introduction}

Knowledge of the foraging strategy is a useful tool in the quantification of the plant-herbivore interaction, knowledge of which is essential to joint studies of grazing management and herbivore performance (Gordon and Iason, 1989). The major sheep genotypes of northern Spain are Churro and Merino and they differ in a number of characteristics which have importance in the utilization of hill pastures. There is limited knowledge about the composition and the nutritive value of roughages ingested under various extensive conditions. This is specially true with regard to the mountain areas of northern Spain where plant communities undergo significant seasonal changes.

The aim of this work was to study the seasonal variation in the diet selected by two different breeds of sheep (Churro $v$. Merino) grazing on a hill shrub community (Calluna vulgaris) of northern Spain.

\section{Material and methods}

The experiment was carried out in northern Spain (Province of León). The experimental field, lay at $1540 \mathrm{~m}$ above sea level, $43^{\circ} 03^{\prime}$ latitude north and $01^{\circ} 41^{\prime}$ longitude west.

Heather cover averaged proportionately $0 \cdot 2115$, and the identified species distribution was $0.151,0.094$ and 0.754 for grass species, legumes and other families respectively.

Table 1 Drymatter (DM) availability $(O, \mathrm{~kg} D M$ per ha) and their leaf $(L)$, stem $(S)$ and twig $(T)$ proportions

\begin{tabular}{lrrrrr}
\hline & & $\mathrm{O}$ & $\mathrm{L}$ & $\mathrm{S}$ & $\mathrm{T}$ \\
\hline Period & 1 & 874 & 0.75 & 0.08 & 0.17 \\
& 2 & 1226 & 0.86 & 0.08 & 0.06 \\
& 3 & 1181 & 0.56 & 0.41 & 0.03 \\
& 4 & 691 & 0.76 & 0.14 & 0.10 \\
\hline
\end{tabular}

Four oesophageally fistulated adult wether lambs of each breed were used for sampling in a delimited $100 \mathrm{~m}^{2}$ area approximately, during 20 to $30 \mathrm{~min}$ in the morning 2 days consecutively, the last week of June, July, August and September 1990. The mean live weights of the Churro and Merino respectively were 37.1 (s.d. 3.02) kg and 45.5 (s.d. 3.11 ) kg. In each period two quadrats $\left(0.25 \mathrm{~m}^{2}\right)$ of grass, were cut to ground level to estimate the dry matter (DM) offered.

The extrusa samples were freeze dried and the grass samples oven dried $\left(60^{\circ} \mathrm{C}\right.$ for $\left.72 \mathrm{~h}\right)$. The leaf, stem and twig were handled separately in the DM of extrusa and DM offered samples.

The selection index $(S I)$ was estimated as the quotient: $S I=D / F$, where $D=$ proportion of leaf, stem or twig in the extrusa samples and $F=$ proportion of leaf, stem or twig in DM offered.

\section{Results and discussion}

There were differences $(P<0.001)$ among periods in the DM availability and in the green leaf mass proportions with a significantly lower value $(P<0.01)$ for the August period (see Table 1); differences that can be explained by the climatology data and the structure of the shrub community.

There were no differences $(P>0.05)$ between breed in the proportion of extrusa leaves $(0.83 \%$ v. $0.86 \%$ for Churro and Merino genotypes respectively; see Table 2).

The effect of period was significantly different $(P<0.01)$ for the leaf proportion. The leaves $S I$ was higher in the Churro breed than in the Merino breed (1.44 v. 1.37, $P<0.01)$, was affected by the sampling time $(P<0.001)$ and had the highest value $(1.14,0.98$, $1.49,1.13)$ in the third period when the proportion of leaves and twig in the DM offered had the smaller value (Milne, Hodgson, Thompson, Souter and Barthram, 1982). The twig SI was only affected 
Table 2 Leaf, stem and twig proportions in dry matter of extrusa

\begin{tabular}{|c|c|c|c|c|c|c|c|c|c|c|c|c|c|}
\hline & & \multicolumn{4}{|c|}{ Leaf proportion } & \multicolumn{4}{|c|}{ Stem proportion } & \multicolumn{4}{|c|}{ Twig proportion } \\
\hline & & \multicolumn{2}{|c|}{ Churro } & \multicolumn{2}{|c|}{ Merino } & \multicolumn{2}{|c|}{ Churro } & \multicolumn{2}{|c|}{ Merino } & \multicolumn{2}{|c|}{ Churro } & \multicolumn{2}{|c|}{ Merino } \\
\hline & & Mean & s.d. & Mean & s.d. & Mean & s.d. & Mean & s.d. & Mean & s.d. & Mean & s.d. \\
\hline \multirow[t]{4}{*}{ Period } & 1 & 0.85 & 0.025 & 0.85 & $0 \cdot 016$ & 0.06 & 0.011 & 0.09 & 0.017 & 0.08 & 0.028 & 0.06 & 0.011 \\
\hline & 2 & 0.87 & 0.020 & 0.82 & $0-030$ & 0.05 & 0.006 & 0.08 & 0.011 & 0.08 & 0.020 & $0 \cdot 10$ & 0.022 \\
\hline & 3 & 0.87 & 0.037 & 0.80 & 0.037 & 0.03 & 0.008 & 0.07 & 0.013 & 0.11 & 0.023 & $0 \cdot 14$ & 0.028 \\
\hline & 4 & 0.86 & 0.033 & 0.85 & 0.025 & 0.03 & 0.008 & 0.03 & 0.007 & $0 \cdot 10$ & 0.025 & $0 \cdot 12$ & 0.019 \\
\hline
\end{tabular}

Table 3 Selection index (SI) of leaf, stem and twig for Churra and Merina genotypes

\begin{tabular}{|c|c|c|c|c|c|c|c|c|c|c|c|c|c|}
\hline & & \multicolumn{4}{|c|}{ Leaf SI } & \multicolumn{4}{|c|}{ Stem SI } & \multicolumn{4}{|c|}{ Twig SI } \\
\hline & & \multicolumn{2}{|c|}{ Churro } & \multicolumn{2}{|c|}{ Merino } & \multicolumn{2}{|c|}{ Churro } & \multicolumn{2}{|c|}{ Merino } & \multicolumn{2}{|c|}{ Churro } & \multicolumn{2}{|c|}{ Merino } \\
\hline & & Mean & s.d. & Mean & s.d. & Mean & s.d. & Mean & s.d. & Mean & s.d. & Mean & s.d. \\
\hline \multirow[t]{4}{*}{ Period } & 1 & $1 \cdot 14$ & 0.033 & $1 \cdot 13$ & $0 \cdot 021$ & 0.82 & $0 \cdot 13$ & $1 \cdot 17$ & 0.22 & 0.48 & $0 \cdot 17$ & 0.36 & 0.06 \\
\hline & 2 & 1.01 & 0.025 & 0.95 & 0.035 & 0.67 & 0.07 & 0.98 & $0 \cdot 14$ & $1 \cdot 31$ & 0.34 & 1.72 & 0.37 \\
\hline & 3 & 1.55 & 0.046 & 1.43 & 0.065 & 0.06 & 0.02 & $0 \cdot 16$ & 0.03 & 3.52 & 0.78 & 4.50 & 0.92 \\
\hline & 4 & $1 \cdot 14$ & 0.043 & $1 \cdot 11$ & 0.033 & 0.23 & 0.05 & 0.24 & 0.05 & 1.04 & 0.26 & 1.20 & 0.19 \\
\hline
\end{tabular}

$(P<0.001)$ by the sampling time $(0.43,1.51,4.04$ and $1 \cdot 13$, see Table 3) (Hodgson, Forbes, Armstrong, Beattie and Hunter, 1991).

\section{Conclusions}

The seasonal variation in intensity of food selection must be considered when the estimation of intake is carried out in mountain sheep grazing systems.

Differences between Churro and Merino genotypes with a higher intensity of food selection in the Churro breed, could be explained as an adaptation response to hard conditions where the quantity of food available is low and the quality of the diet must compensate the animal requirements.

The variation in the selection index among periods and the differences between breeds can be used in the heather shrub control, separately or not depending on the aims of the countryside conservation and the pasture utilization.

\section{References}

Gordon, I. J. and Iason, G. R. 1989. Foraging strategy of ruminants: its significance to vegetation and management. Macaulay Land Use Research Institute, Anmual Report 1988, pp. 34-41.

Hodgson, J. A., Forbes, T. D. A., Armstrong, R. H., Beattie, M. M. and Hunter, E. A. 1991. Comparative studies of the ingestive behaviour and herbage intake of sheep and cattle grazing indigenous hill plant communities. Journal of Applied Ecology 28: 205-227.

Milne, J. A., Hodgson, J., Thompson, R., Souter, W. G. and Barthram, G. T. 1982. The diet ingested by sheep grazing swards differing in white clover and perennial ryegrass content. Grass and Forage Science 37: 209-218. 